\title{
Türk Sineması ve Şiddet: Son Dönem Türk Filmlerinde Şiddetin Sunumu Üzerine Bir Araştırma
}

\section{Turkish Cinema and Violence: A Research on Presentation of Violence in Recent Turkish Films}

\author{
Fatih Söğüt \\ Dr. Öğr. Üyesi, Kırklareli Üniversitesi Sosyal Bilimler Meslek Yüksek Okulu Radyo-Televizyon Programcılığı \\ email: fatih.sogut@klu.edu.tr (DORCID ID: https://orcid.org/0000-0001-6529-9056
}

iThenticate' Bu makale bilimsel etik ve kurallara uygun hazırlanmış ve intihal incelemesinden geçirilmiştir

Atıf (APA 6)/To cite this article

Söğüt, F. (2020). Türk sineması ve șiddet: son dönem Türk filmlerinde șiddetin sunumu üzerine bir araștırma. Atatürk Üniversitesi Güzel Sanatlar Enstitüsü Dergisi, 26(44), 246-257. doi: https://doi.org/10.35247/ataunigsed.674233

Makale Gönderim Tarihi/Received: 13/01/2020

Makale Kabul Tarihi/Accepted: 11/03/2020

Makale Yayın Tarihi/Published: 19/03/2020

Research Article / Araștırma Makalesi

\section{Öz}

Siddet, en eski tarihlerden bu yana insanlığın ve kültürün bir parçasıdır. Kültürel bir olgu olarak değerlendirildiği için şiddettin sunumu resim, müzik, edebiyat ve sinema eserlerinde görülmektedir. Bu bağlamda bu çalışmayla amaçlanan Türkiye'de yüksek sayıda izleyici tarafindan seyredilen filmlerdeki şiddet içeriğini ortaya çıkarmaktır. Bu amaç doğrultusunda son bes yılda en çok izlenen filmler; Müslüm (2018), Recep Ivvedik 5 (2017), Recep İvedik 4 (2014), Düğün Dernek 2 (2015), Dă 2 (2016) örneklem olarak alınarak bu filmlere içerik analizi uygulanmıştır. Yapılan analiz sonuçlarına göre bazı şiddet türlerinin öne çıktığı, filmlerde siddete maruz kalanların cinsiyete göre dağılımında erkeklerin kadınların önünde olduğu, yine filmlerde şiddetin failinin çoğunlukla erkekler olduğu, siddet biçimlerinin genellikle ikili diyaloglarda ya da birbirine yabancı film kișileri arasında gerçekleştiği görülmüştür.

Anahtar kelimeler: Siddet, Türk Sineması, İcerik Analizi

\begin{abstract}
Violence has been a part of humanity and culture throughout the history. Since it is considered a cultural phenomenon, the presentation of violence is seen in paintings, music, literature and cinema. In this context, the purpose of this study is to expose the violent content in films watched by a high number of viewers in Turkey. For this purpose, the most watched films in the last five years; Müslüm (2018), Recep İvedik 5 (2017), Recep İvedik 4 (2014), Düğün Dernek 2 (2015), Dağ 2 (2016) were taken as samples and content analysis was applied to these films. According to the results of the analysis, it is understood that some types of violence come to the fore in the films. In the distribution of the victims of violence according to gender, men are ahead of women. Again the perpetrators of violence in the movies are mostly men. Forms of violence usually occur in bilateral dialogues or between foreign film persons.
\end{abstract}

Keywords: Violence, Turkish Cinema, Content Analysis

\section{Giriș}

Şiddet tüm dünyada gündeme gelen ve hakkında pek çok araştırmanın yapıldığı bir olgudur. Şiddet, Türk Dil Kurumu sözlüğünde "karşıt görüşte olanlara kaba kuvvet kullanma, kaba güç, duygu ve davranışlarda aşırılık olarak tanımlanmıştır." Şiddet, toplumumuzda her yönüyle tartışılan bir konu olmuştur.

Şiddetin birey üzerinde yarattığı etki, ruhsal ve fiziksel düzeyde olmaktadır. Şiddetin bir diğer yönü de insanlar arasında meydana gelmesidir. Şiddeti ortaya çıkaran bazı etkenler bulunmaktadır. Özellikle bireyin sahip olduğu psikolojik ve biyolojik özellikler şiddet davranışının ortaya çıkmasında etkili olabilir. Bunun dışında şiddeti doğuran nedenler arasında sosyal, kültürel ve ekonomik faktörler etkili olabilmektedir. İşsizlik ve yoksulluk, şiddetin oluşmasına etki eden ekonomik faktörleri oluşturmaktadır.

Birey, içinde bulunduğu toplumsal yapı içinde sosyal, kültürel ve ekonomik anlamda sosyalleşir. Birey sosyalleştikçe ait olduğu toplumun davranış kalıplarını edinir. Sosyal hayatta ortaya çıkan şiddet, aslında bireylerin birbiri ile etkileşiminden doğan sosyal bir olgudur.

Şiddetin sosyo-kültürel ve ekonomik kökenlerine bakıldığında, rol-model alma davranışının etkili olduğu görülür. Birey, şiddeti içinde yaşadığı sosyal yapıda doğrudan ya da dolaylı olarak öğrenmektedir. Çocukluktan itibaren birey aile içi şiddetle karşılaştıkça şiddete eğilimli bir kişiliğe sahip olmaktadır.

Şiddet konusunda bireyi şekillendiren ona rol-model olan kaynaklardan biri de medyadır. Günümüzde medya araçları insan hayatının her alanında etkili olmaktadır. Bu duruma bağlı olarak medyanın insanlar üzerindeki etkisi çok fazladır. Medya araçları insanlara çeşitli mesajlar gönderirler. Verilen bu mesajlarda temel amaç yüksek bir izleyici/okuyucu kitlesine ulaşabilmektir. Medyanın çok izlenme çok okunma çabası içerisinde mesaj içeriklerinde şiddetin önemli bir yeri vardır.

Medya, kültürün önemli bir dağıtıcısıdır. Medya çeşitli işlevler üstlenerek kitleyi kendine çekmeye çalışan gelişmiş bir ağdır. Teknolojinin ilerlemesi insanların medyaya olan ihtiyacını arttırmıştır. Günümüzde insanlar eğlenme, haber alma, sosyalleşme gibi etkinlikler için medyayı kullanmaktadır. Medya insanlara sunduğu bu olumlu yönlerinin yanı sıra şiddet olgusunun toplumca normalleştirilmesi gibi olumsuz bir yöne de sahiptir. 
Hem bir medya aracı hem de bir sanat olan sinema, kitleler tarafından büyük bir ilgiyle takip edilmektedir. Sinema filmleri insanlar için önemli bir serbest zaman etkinliğidir. Bu noktada sinemadaki şiddetin pek çok insanı etkilediği açıktır. Sinemadaki şiddet içeriğinden en çok etkilenme potansiyeline sahip olanlar henüz benlikleri oturmamış olan gençler ve çocuklardır. Sinemadaki şiddet üzerine yapılan araştırmalarda şiddet sahnelerini izleyen genç ve çocuk kitlenin bu sahnelerden olumsuz etkilendiklerini göstermiştir.

Bu çalışmada Türk Sinemasında şiddet içeriğinin ortaya çıkarılması amaçlanmaktadır. Son yıllarda Türk Sineması yoğun bir izleyici kitlesi tarafından takip edilmektedir. Artan sinema salonları ve izleme olanakları sayesinde artık Türk filmleri çok sayıda izleyiciye ulaşabilmektedir.

Türk Sinemasında dönem dönem şiddet içeren filmlerin varlığından söz edebiliriz. Özellikle tarihi ve polisiye filmlerde sık sık şiddet içeren sahneler vardır. Şiddetin niteliği olarak Türk Sinemasında bir çeșitlilik söz konusudur. Fiziksel şiddet olarak; tokat, kavga sahneleri öne çıkarken zengin-fakir, modern-geleneksel çatışmasına dayalı filmlerde duygusal şiddet görülür.

Çalışmanın ilk bölümünde şiddete yönelik kuramsal çerçeveyi çizmek için literatür taramasıyla elde edilen bilgiler sunulmuştur. Araştırmanın ikinci bölümünde ise Türkiye'de son 5 yılda en çok izlenen filmlerdeki şiddet olgusu içerik analizi yöntemi ile belirlenmiştir. İçerik analizi ile elde edilen veriler sayısal verilere dönüştürülerek yorumlanmiştır.

\section{1. Şiddetin Tanımı}

Şiddet kavramı toplumdan topluma, zamandan zamana ve şiddeti ele alan kişinin bakış açısına göre değişebilir. Bu nedenle de şiddetin tam ve kesin bir tanımını yapmak zordur. Toplumsal bir kavram olarak şiddet, toplumsal değişmeye bağlı olarak niteliksel değişimler göstermiştir.

Etimolojik olarak Arapça kökenli bir sözcük olan şiddetin tekil kullanımı "şidd”, çoğul kullanımı ise "şiddad”tır. Sertlik ve katılık anlamlarına gelmektedir. Türkçe sözlük bugün şiddet sözcüğünün açıklamasını "1. Bir hareketin, bir gücün derecesi, yeğenlik sertlik; 2.hız: rüzgârın şiddeti; 3. Mecaz (duygu ve davranış için) aşırılık" ("Türk Dil Kurumu", t.y.) olarak yapmaktadir.

Şiddet üzerine yapılan çalışmalarda araştırmacıların şiddet ile ilgili görüşleri farklı olabilmektedir. Balcıoğlu (2001), şiddeti "bireye ya da topluma fiziksel ve ruhsal acı vermek, eziyet niyeti ile yapılan yıkıcı, yok edici saldırgan davranışlar" olarak tanımlamıştır (s. 20). Köknel (2000) şiddeti, öfke, kin, nefret, düşmanlık gibi duygu durumlarının etkinlik kazandığı saldırganlık biçimi olarak tanımlamıştır; ayrıca Köknel'e göre şiddet: "saldırgan davranışları; kaba kuvveti, beden gücünün kötüye kullanılmasını; yakan, yıkan, yok eden eylemleri; taşlı, sopalı, silahlı saldırıları; bireye ve topluma zarar veren etkinlik" olarak da ifade edilebilir (s. 21). Tekin'e göre (2011) ise, şiddet küresel anlamda kötü bir eylem biçimi olduğu gibi bireyler ve toplumlar bazında da farklılaşabilen ve birçok biçimde kendini var eden karmaşık bir eylem biçimidir (s. 1). Tekin'in de vurguladığı gibi şiddet evrensel bir nitelik taşır.

Şiddet, güce dayalı bir olgu olarak kişiyi öldürme, yaralama ve sakat bırakma gibi fiziksel eylemleri kapsayabileceği gibi kişinin duygusal yaşamına da hedef alan eylemleri de kapsayabilir. Bu noktada bireyin sahip olduğu mallara yönelik eylemlerde şiddet olarak değerlendirilebilir.

Hayatın her yönünde karşımıza çıkan şiddet siyasal yaşamda da tartışılan bir konudur. Yürürlükteki siyasal sistemlerin ancak şiddet yoluyla değiştirilebileceğine inanan anarşist ya da radikal siyasal görüşlerde bulunmaktadır. Örneğin faşizm, savaşı kutsayan; devleti daha da güçlendiren bir olgu olarak şiddeti meşrulaştıran bir siyasi görüştür.

Şiddetin hukuksal yönü de üzerinde durulması gereken bir konudur. "Ağır suç kapsamına giren şiddet (cinayet, yaralama, ırza tecavüz, silahlı saldırı, gasp) gibi olayların yanı sıra, daha hafif kabul edilen şiddet olayları da (trafik suçu, tehdit) Ceza Yasası'nın kapsamında cezalandırılır” (Ünsal, 1996, s. 30). Devlette kolluk güçleri vasıtasıyla şiddet uygulayabilir. Ancak bu durum devlete verilen zor kullanma hakkıyla ilgilidir. Ünsal'a (1996) göre, devletin uyguladığı bu şiddet, kaba kuvvet değil, toplum adına kullanılan zorunlu ve meşru bir güç, daha doğrusu araçtır (s. 30). Bu bağlamda Batı normlarına göre kendisine verilen şiddet kullanma yetkisini kötüye kullanan bir dikta rejimiyle mücadele kapsamında şiddete başvurmak meşru bir hak olarak görülebilir.

Davranış bilimlerinde de şiddete ilişkin araştırmalar yürütülmüştür. Bu araştırmalarda genel amaç bireyde şiddete yol açan etkenleri ortaya çıkarmaktır. Moses'a (1996) göre, şiddete eğilimli bir kişide onu şiddet eğilimli davranışa götüren en önemli etkenler, yetersiz kalan ana-baba-çocuk-aile ilişkisi, aile şefkati ve ayrıca nesilden nesile aktarılan şiddet içeren davranış biçimleridir (s. 24). Çocuklar üzerine yapılan bir araştırma, çocukların şiddeti depresyonu ortadan kaldıran bir davranış biçimi olarak gördüklerini ortaya çıkarmıştır (Burks ve Harrison, 1962). Şiddetin ortaya çıkışında işsizlik ve yoksulluk önemli bir faktör olarak görülebilir. Bunun dişında şiddet sosyal topluluklarda da aniden ortaya çıkan gerginliklerde ortaya çıkabilir. Aile içi şiddet, kan davası ve töre cinayetlerini bu duruma örnek olarak verebiliriz. 
Şiddet olgusunu ruhbilimsel olarak farklı bir bakışla değerlendiren Sigmund Freud, şiddetin insanın içinde olan bir içgüdü olduğunu vurgulamıştır. Freud, bu içgüdüyü "Ölüm İçgüdüsü" olarak adlandırmıştır. Freud'a göre, insan şiddet ve ölüm içgüdüsü ile doğmuştur; öldürme insanın doğasında vardır (aktaran Erten ve Ardalı, 1996, s. 160) Freud'un şiddet üzerine olan bu görüşlerini etkileyen temel noktanın birinci dünya savaşı sonrası özellikle Avrupa da ortaya çıkan insanın ve toplumun geleceğine yönelik karamsar düşünceler olduğunu da belirtmek gerekir.

Şiddet kavramını daha iyi anlayabilmek için, kavramı kategorilere ayırıp incelemek gerekmektedir. Bu da bize değişik şiddet türlerini anlamada yardımcı olacaktır.

\section{2. Şiddetin Türleri}

Şiddet türlerini kategorileştirmek şiddeti tanımlamak kadar zordur. Belirli bir sınıflandırma yapılırsa alt kategoriler arasında bir benzeşme ortaya çıkabilir. Bu bağlamda şiddet türlerini birbirinden bağımsız şekilde alt başlıklar halinde kategorilendirmek doğru olacaktır. Bu ayrım yapılırken, Gümüş'ün (2006) şiddet türleri ile ilgili yaptığ çalışma dikkate alınmıştır.

\subsubsection{Fiziksel Şiddet}

Bir insanın canının acımasına, yaralanmasına hatta ölümüne sebep olabilecek kasıtlı davranış biçimidir. Di Martino'ya (2003) göre fiziksel şiddet, "Vurma, tekmeleme, tokatlama, bıçaklama, silahla vurma, 1sırma, cinsel saldırı ve benzeri yollarla fiziksel olarak yaralanma içeren davranışları" ifade eder (s. 18). Michaud'a (1991) göre ise, "fiziksel şiddet; bir canlının, nesnenin, kişi ya da grupların bedensel ve maddi bütünlüğüne zarar verilmesi ile ortaya çıkar" (s. 7). Michaud'un tanımından yola çıkarak cinayet, yaralama, işkence, tecavüz, linç, terör saldırısı, boğuşma, 1sırma, intihar, el şakaları, kundaklama, gibi eylemler fiziksel şiddet olarak değerlendirilebilir.

Fiziksel şiddet dayaktan çok farklı boyutları olan bir şiddet türüdür. Kaba güçle olabileceği gibi çeşitli aletler kullanılarak fiziksel şiddet uygulanabilir. Çoğu insan için şiddet denilince akla fiziksel şiddet gelmektedir. Fiziksel şiddet en s1k rastlanılan ve bilinen şiddet türüdür.

\subsubsection{Duygusal Şiddet}

Kişinin haysiyetini hedef alan ve etkisi en az fiziksel şiddet kadar ağır olan bir şiddet biçimidir. Bireyi psikolojik olarak üzüntüye sevk eden, aynı zamanda bireyi baskı altına alan bütün davranış biçimlerini ifade eder. Bağırmak, hakaret etmek, aşağılamak, kişinin bireysel ve sosyal yaşamına karışmak gibi davranışlar duygusal şiddete girmektedir.

Duygusal şiddetin farklı bir yönü de sözel şiddeti de kapsıyor olmasıdır. "Sözel şiddet; söz ve hareketlerin düzenli bir şekilde korkutma, sindirme ve cezalandırma aracı olarak kullanılmasıdır” (Polat, 2017, s. 31). Sözel şiddet de duygusal şiddet gibi kişinin haysiyetine yönelik bir davranış biçimidir.

\subsubsection{Cinsel Şiddet}

Kişinin cinsel bir nesne gibi görülmesi ve cinsel dokunulmazlığını aşan seviyede taciz ve tecavüz gibi davranışlara maruz kalmasıdır. Cinsellik yoluyla kişiyi tehdit etmek, korkutmak gibi davranışlarda cinsel şiddet olarak kabul edilmektedir.

Cinsel şiddet bütün toplumları ilgilendiren evrensel bir nitelik taşımaktadır. "Kadınlara yönelik şiddetin açık bir göstergesi olarak, tecavüz ve cinsel tacizi de içeren cinsel şiddet evrenseldir; devlet sınırlarını ve kültürleri aşmaktadır" ("Birleşmiş Milletler”, 2009, s. 4). Kadına ve çocuklara yönelik cinselliklerini şiddet, korku ve sindirme yoluyla kontrol altına almak olarak da değerlendirilebilir.

Dünya Sağlık Örgütü’ne (2002) göre, cinsel şiddet; “çocuğa, gence, kadına, erkeğe ve/veya hayvanlara yönelik olarak izleme, teşhir etme, laf atma, el kol hareketi yapmakla başlayıp tecavüze kadar uzanan” cinsel içerikli her türlü eylem olarak tanımlanmaktadır. Cinsel şiddetin insani boyutu dışında hukuki boyutu da bulunmaktadır. TCK'ya göre cinsel dokunulmazlığa yönelik her türlü eylem (laf atma, cinsel saldırı gibi eylemler) suç olarak kabul edilir.

\subsubsection{Ekonomik Şiddet}

Kişinin kendi rızası dışında ekonomik faaliyetlerinin kontrol edilmesidir. Gürkan ve Çoşar'a (2009) göre, ekonomik şiddet: "ekonomik kaynakların ve paranın birey üzerinde bir yaptırım, tehdit ve kontrol etme aracı olarak kullanılmasıdır” (s. 2). Beslenme, barınma gibi temel ihtiyaçlarda kişiyi zor duruma sokar. Para vermemek, paranın nasıl harcanacağına karışmak, yeteri kadar para vermemek ve ekonomik konularda kişinin görüşlerini önemsememek gibi davranışlarda ekonomik şiddet olarak değerlendirilebilir.

\subsection{Televizyondan Sinemaya Şiddet Olgusu}

1960'l1 yıllardan bu yana televizyonda yer alan şiddetin insanları olumsuz yönde etkilediği onları suça yönelttiği tezi ileri sürülmektedir. Televizyondaki şiddet olgusunu araştıran ilk çalışmalardan biri olan "Content Analysis of 
Television Drama Programs"araştırmasına göre TV programlarında en fazla görünen şiddet biçimleri: silahlı çatışma, cinayet ve kavga olmuştur (Head, 1954). Turam'a (1996) göre, "Head'in incelediği programların hiçbirinde tecavüz olayına rastlanmamaktaydı ve TV programlarında gerçeklerin böylece saptırılmış olduğu açıkça görülmekteydi” (s. 399). Bu araştırmanın dışında Amerikan televizyonlarında şiddetle ilgili USA Today gazetesi tarafından yapılan bir başka araştırmaya göre Amerika'nın en çok seyredilen beş televizyon kanalında (CBS, NBC, ABC ve Fox TV) prime time zaman dilimi olarak adlandırılan 19:30-22:30 saatleri arasinda incelenen TV programlarında en çok rastlanan şiddet biçimi \%30'luk oran ile kavga olurken onu \%26 ile silahsız saldırı, \%12'si silahlı saldırı, \%3’ü ise toplu katliam olmuştur.

Ortaya konan rakamlar, bir insanın, örneğin televizyonda uğradığı şiddet sayılarıyla bir araya geldiğinde daha bir anlamlı olmaktadır. Gerbner'e (1998a, s. 24; 1998b, s. 139) göre, "bugüne kadar insanlık çok fazla kan akışına tanık olmuştur". Ama, günümüzdeki gibi şiddet imgeleriyle hiçbir zaman karşı karşıya gelmemiştir. "1974'te şiddet içerikli program sayısı 58 iken, bu sayı 1984'te 73'e; 1994'te ise 75'e çıkmıştır” (Gerbner, 1998b, s. 26). "Şiddet, her 10 programın en azından 6'sında görülmektedir. En çok izlenen zamanda, saat başı 5 şiddet sahnesi yer almakta, ortalama her geceye 2 ya da 3 cinayet düşmektedir" (Gerbner ve diğerleri, 1980). "Her 4 ya da 5 haberden biri şiddet içerikli olmaktadır" (Gerbner, 1996, s. 27). Cumartesi sabah çocuk programlarında saat başı şiddet sahnesi sayısı 20-25 arasını bulmaktadır. "The Committee on Communications of American Academy of Pediatrics' in açıkladığına göre, 18 yaşına kadar insanlar sadece televizyonda, yaklaşık olarak 200 bin şiddet eylemi görmektedirler" (Bagdikian, 2000, s. 36).

Türkiye' de ise Gül Özbay ve Neşe Kutlu’nun 1993 yılında Milliyet gazetesi için yaptıkları araştırmada, yedi ayrı TV kanalının (TRT 1, TRT 2, Star, Show TV, ATV, HBB, Kanal 6) yayınları incelemiştir. Bu araştırmaya göre 09:00-23:00 saatleri arasında incelenen TV yayınlarında yaklaşık 500'e yakın kişi ölürken 600'den fazla da yaralanma vakası görülmekteydi. Ölüm nedeni olarak da en çok patlama, zehirlenme ve cinayet vakaları gelmektedir.

Türkiye'de, TV'de gösterilen filmlerdeki şiddeti araştıran bir çalışmada örneklem olarak seçilen beş özel televizyon (Atv, Star, Show tv, Kanal D, TGRT) kanalında hafta içi yayınlanan 80 filmde toplam sürenin \%33'ünde şiddet içeriğinin olduğu saptanmıştır (Ayrancı ve diğerleri., 2004, s. 138).

Televizyonda sunulan şiddetin gerisinde kâr etme amacı bulunmaktadır. "Medya ve kâr bir arada düşünüldüğünde, en öne çıkan unsur şiddet olarak belirmektedir" (Özer, 2017, s. 5). Şiddet, toplum tarafından cazip görülen bir içerik türüdür. Çok izlenen filmlerin ve dizilerin araştırmalara yansıyan şiddet içeriğinin yoğunluğu bu tezi doğrulamaktadır. Popüler bir içerik olarak şiddet kolay üretilir ve kolay tüketilir. Şiddetin evrensel bir olgu olması şiddet içeren yapımların küresel ölçekte yayılmasını kolaylaştırmaktadır.

Reklam içinde en ilgi çekici içerik türlerinden biri şiddettir. "Çoğu zaman, ticari mesajlar açısından en uygun zihinsel set içinde bulunan izleyicileri, reklamcılara teslim etmek için gereklidir" (Özer, 2010, s. 15). Sinema ve televizyon endüstrisi, reklam gelirleri için çok sayıda izleyici toplamak istemektedir. Hedefteki kitle ise genç insanlardır. "Gençleri ekran başına toplamak için en uygun araç ise şiddettir" (Potter, 1999, s. 157).

Sinema ortaya çıktığı ilk dönemlerden bu yana şiddet ile iç içedir. Trend'e (2008) göre, "ilk filmlerin merkezi şiddettir. Thomas Edison 1895'te 30 saniyelik bir kafa kesme klibi olan Kinetoskop filmi The Execution of Mary, Queen of Scots ile yeni teknolojiyi sergiler" (s. 24). Özellikle teknolojik imkanların gelişimiyle şiddettin sinemadaki görünürlüğü artmıştır.

Filmlerin renklenmesiyle özellikle fiziksel şiddet içeren sahneler izleyiciye daha gerçekçi bir şekilde sunulmuştur. Sinemada şiddeti daha belirgin kılan bir diğer teknik gelişme ise sesin sinemaya girişidir. Sesin kullanımıyla beraber sinemadaki şiddetin etkisi daha da artmıştır. Özel Efekt teknolojilerinin de ortaya çıkmasıyla Charlie Chaplin, Harold Lloyd ve Buster Keaton gibi komedi yıldızları izleyicinin ilgisini daha fazla çekebilmek için düşme, çarpışma, kaza ve diğer şiddet öğelerini öne çıkarmışlardır.

Amerikalı yönetmen Edwin Porter'ın yönettiği 1903 tarihli Great Train Robbery ve David Wark Griffith tarafindan yönetilen 1915 tarihli Intolarance filmleri içerdikleri silahlı çatışma sahneleri ile dikkat çekmişlerdir. Sessiz film döneminden sonra yapılan komediler güldürü etkilerini yükseltmek ve izleyicilerin heyecanını devamlı kılmak için kullanılan şiddet için bazı eğilimler geliştirdiler. Vodvil türünün tekniklerini alan ilk komedi filmleri, öykülerini daha hareketli ve "komik" hale getirmek için kavga, felaket ve yıkımla doluydu.

Türk Sinemasının ilk yıllarında da filmlerde şiddete rastlanmaktadır. "Muhsin Ertuğrul'un yönetmenliğini yaptı̆̆ı Istanbul'da Bir Facia-i Aşk (1922) filminde şiddet sahnelerinin varlığına izleyiciler tanık olmuştur" (Teksoy, 2007, s. 19). Ömer Lütfi Akad'ın ilk filmlerinden biri olan Vurun Kahpeye (1949) filminde de şiddet sahneleri dikkat çekicidir. Bu filmin baş karakteri olan Aliye, köylüler tarafından linç edilmektedir. Yine Lütfi Akad'ın filmlerinden biri olan Kanun Namına (1952) filminde de adam öldürme ve silahlı çatışma gibi şiddet öğeleri bulunmaktadır. Metin Erksan'ın Kuyu (1968) filminde kadına yönelik şiddet sahneleri bulunmaktadır. Türk Sinemasında, tarihi filmler de şiddet içeriği açısından oldukça zengindir. Tarkan ve Malkoçoğlu serileri gibi tarihi 
filmlerde ya da mafya çatışmalarını konu edinen filmlerde fiziksel şiddet eylemlerine oldukça sık rastlanmaktadır. Genel olarak bakıldığında çoğu Yeşilçam filminde şiddet, bir şekilde görülmektedir. Yeşilçam filmlerinde fiziksel şiddet genellikle tokat, kavga şeklinde olsa da zaman zaman silahlar patlamaktadır. Bunun dışında Yeşilçam filmleri sadece fiziksel değil, aynı zamanda özellikle melodram filmlerinde görülen duygusal şiddet içeriği açısından da oldukça zengindir.

Toplumsal ilişkilerin yaratıcılarından olan sinema, Süalp'e (1993) göre “şiddet anlatısını görüntü ve söylem olarak üretirken, şiddetin toplumsal düzeyde yeniden kavramsallaştırılmasına ve yeniden üretimine katılır” (s. 2). Süalp’in de vurguladığı gibi sinemanın şiddetin üretilmesinde ve yayılmasındaki rolü yadsınamaz.

Ana akım sinemada özellikle de Amerikan Sinemasında şiddet sıklıkla anlatının bir aracı değil, anlatının kendisidir. "Şiddet, sinemada izleyicinin uygulanmasını haklı bulabileceği, estetize edilmiş bir içerikle sunulur" (Kalkan, 2018, s. 70). Şiddetin nedeni, işleniş şekli ve kurbanlardaki sonuçları en sert haliyle gösterilir. Hollywood filmlerine özgü klişelerin kullanımıyla şiddet olgusunun meşru hale getirilmesi ve izleyici tarafından özümsenir şekle sokulması söz konusudur. İntikam almak gibi şiddet çağrıştıran eylemler görsel efektlerin kullanımıyla izleyiciye sunulur. Hollywood filmlerinde kahramanlar şiddet üzerinden izleyiciye kabul ettirilirler.

Hayatın gerçeklerinden yola çıkan sinema sanatı hayatın içindeki şiddet olgusunu da biçim ve içerik olarak izleyicisine sunmaktadır. "Şiddet günlük yaşamımızdan soyutlanamayacak bir olgudur ve sinemanın da yaşamdan beslenen bir sanat dalı olduğu bir gerçektir. Dolayısıyla sinema filmlerinde şiddet de dahil hemen her içeriğe yer vardır" (Temel, 2008, s. 23). Ancak buradaki önemli nokta sinemanın şiddeti nasıl sunduğudur.

Sinemanın şiddeti pek çok yolla sunma biçimi vardır. Şiddetin sunumu, izleyici üzerinde yaratılmak istenen etkiye göre, yapımın bütçesine göre ve senaryoya göre değişebilir. Şiddetin en açık biçimiyle gösterimi şiddet eylemlerinin hem görsel hem de işitsel bir öğe olarak sunulmasıdır. Doğrudan şiddeti göstermek sinemada sıklıkla karşımıza çıkan bir durumdur. Çatışma, cinayet, boğuşma, işkence gibi eylemlerin bütün işitsel ve görsel unsurlarıyla yalın bir biçimde sunumu buna örnek olarak gösterilebilir.

Şiddeti apaçık göstermek yerine çeşitli yollarla gizlemek ya da ima etmekte sinemada şiddetin sunumuna farklı bir yaklaşımdır. Sinemanın anlatım olanaklarıyla şiddet eylemi izleyiciden gizlenebilir. Örneğin; görüntünün kararması, kameranın çevrinmesi gibi teknikler bu amaç için kullanılabilir.

Sinema ve şiddet ilişkisi pek çok akademik araştırmaya konu olmuştur. Gökulu (2013), yaptığ "Representation of Sexual Violence in Turkish Cinema and Television Series" başlıklı araştırmasında Türk dizilerinde ve sinema filmlerindeki cinsel şiddetin sunumunu araştırmıştır. Bu araştırmanın sonuçlarına göre Türkiye'de yayınlanan dizilerde ve gösterime giren sinema filmlerinde cinsel şiddet önemli bir yer tutmaktadır. Abisel (2005), 300 Türk filmi üzerine yaptığı araştırmada kadına yönelik şiddeti incelemiştir. Bu araştırmanın sonuçlarına göre filmlerin sadece 7'sinde kadınlara yönelik şiddet tespit edilmemiştir (s. 313). Erdal Aytekin (2015), "Zeki Demirkubuz Sinemasında Şiddet: Masumiyet ve Kader" başlıklı çalışmasında Demirkubuz'un bir yönetmen olarak yarattığı atmosferle "şiddeti, film dili üzerinden görünür hale getirdiğini”" vurgulamıştır (s. 176). Pişkin'in (2007), "Hızlı ve Dengesiz Değişime Tepki Olarak Sinemada Şiddet: Türkiye Örneği: 1980-2006” başlıklı çalışmasında “Türk filmlerinde şiddet eylemlerinin yüksek amaçlara uygun olarak gerçekleştirildiği için haklılaştırıldığını” belirtir (s. 592). Özer ve Saraçer Üçer'in (2010), "Baba 1 ve Kurtlar Vadisi Irak Filmleri Örneğinde Sinemada Şiddetin Kullanımı" başlıklı çalışmasında incelenen iki filmde de şiddete yoğun bir biçimde yer verildiği ve bu filmlerde şiddetin, filmlerin vermek istediği mesajın önü geçtiği sonucuna varılmıştır.

Amerikan Sineması üzerine 2002 yılında Browne, Webb, Fisher ve Cook tarafindan yapılan bir araştırmada örneklem olarak alınan 100 filmde toplam 2148 şiddet eylemi gerçekleşmiştir. Bu sonuçlara göre bir Amerikan filminde ortalama 21.4 şiddet eylemi düşmektedir. David Slocum, "Film Violence and the Institutionalization of the Cinema" isimli makalesinde Amerikan Sinemasındaki şiddetin dönemsel ve türlere özgü yansımasını sunmuştur. Bryan Stone, 2016 yılında yazdığ "Religion and Violence in Popular Film" makalesinde din-şiddetsinema ilişkisini irdelemiştir. Bu çalışmaya göre sinema filmlerinde dinsel öğeler şiddeti haklılaştırmak için kullanılmaktadır.

\section{Yöntem}

Bu araştırmada nitel içerik analizi yöntemi uygulanmıştır. Berelson'a (1952) göre, içerik analizi “iletişimin belirgin yazılı/açık içeriğinin objektif, sistematik ve niceliksel tanımlarını yapan bir araştırma tekniğidir" (s. 7). Krippendorf (1980) ise, içerik çözümlemesini "metinlere ve kullandıkları bağlamlara yönelik anlamlı, tekrarlanabilir ve geçerli çıkarımlar yapmak için faydalanılan bir araştırma tekniği”" olarak tanımlamaktadır (s. 18). İçerik analizini kullanarak filmlerdeki şiddet eyleminin ölçümlenebilmesi ve yorumlanabilmesi mümkündür. Bu araştırmanın amacı son dönem Türk filmlerinde şiddet içeriğini ortaya çıkarmaktır. Bu amaca uygun olarak aşağıdaki araştırma soruları belirlenmiştir.

1- Filmlerde sergilenen şiddetin türü nedir? 
2- Filmlerde sergilenen fiziksel şiddet türleri nelerdir?

3- Filmlerde sergilenen duygusal şiddet türleri nelerdir?

4- Filmlerde şiddete maruz kalanların cinsiyete göre dağılımı nedir?

5- Filmlerde faili erkek olan şiddet eylemleri ve şiddetin türü nedir?

6- Filmlerde Faili kadın olan şiddet eylemleri ve şiddetin türü nedir?

Bu çalışmanın evrenini 2014-2018 yılları arasında gösterime giren Türk filmleri oluşturmaktadır. Örneklem belirlenirken, "araştırmacının kendi amacı ve yargısına uygun olarak hangi birimlerin örnekleme gireceğini saptadığ1 amaçsal örneklem alma tekniği”” (Atabek \& Atabek, 2007, s. 12) kullanılmıştır.

Örneklem olarak 5 yıllık dönemde en çok izlenen filmler kıstas alınmıştır. boxofficeturkiye.com sitesinden elde edilen veriler doğrultusunda en yüksek gişe hasılatı elde eden 5 film örneklem olarak seçilmiştir. Bu filmler; Müslüm (2018- 44.635.574 seyirci), Recep İvedik 5 (2017-40.325.495 seyirci), Recep İvedik 4 (2014-35.777.989 seyirci), Düğ̈̈n Dernek 2 (2015-34.273.257 seyirci), Dă̆ 2 (2016-31.102.760 seyirci)

Örneklem içindeki filmlerin şiddet içeriğini tespit edebilmek için; "birim veya öğelerin sayısal, yüzdesel ve oransal bir tarzda görünme sıklığını ortaya koyan frekans analizi tekniğì” (Bilgin, 2006, s.18) kullanılmıştır. Çalışmanın literatür taraması kısmından şiddet ile ilgili elde edilen veriler doğrultusunda ve araştırma soruları çerçevesinde kategori tablosu oluşturulmuştur.

Kodlama işleminde araştırmacıyla beraber 5 kişi görev almıştır. Kodlamayı yapacak olan kişilere araştırmacı tarafından kodlamanın nasıl yapılacağına ilişkin bilgiler verilmiştir.

Kodlayıcıların güvenirlilik testi için Holsti’ye (1969) ait olan formülden faydalanılmıştır (s. 129). Bu formüle göre: Güvenilirlik=5M/N1+N2+N3+N4+N5 bu formülasyondaki M değeri üzerinde uzlaşılan kodlama sayısını, $\mathrm{N}$ değeri ise kodlayıcıların her birinin yaptığı kodlama sayısını ifade etmektedir. Bu formüle göre kodlayıcılar arasındaki uyumluluk \%95 çıkmıştır.

\section{Bulgular}

Filmlerde sergilenen şiddetin türü kategorisinde \%47,5'lik oran ile fiziksel şiddet öne çıkmaktadır. Fiziksel şiddet kadar yoğun olan bir başka şiddet türü de duygusal şiddettir. Duygusal şiddet eylemlerinin oranı \% 46,6 olarak tespit edilmiştir. Örnekleme dahil edilen 5 film içinde şiddet davranışı en fazla olan film Recep İvedik 4 filmi olmuştur. Bu filmi sırasıyla Recep İvedik 5, Müslüm, Düğ̈̈n Dernek 2 ve Dă̆ 2 filmi seyretmiştir.

Tablo 1

Filmlerdeki şiddetin türü

\begin{tabular}{|c|c|c|c|c|c|c|c|c|c|c|}
\hline \multirow{2}{*}{ Film Adı } & \multicolumn{2}{|c|}{ Fiziksel Şiddet } & \multicolumn{2}{|c|}{ Duygusal Şiddet } & \multicolumn{2}{|c|}{ Cinsel Şiddet } & \multicolumn{2}{|c|}{ Ekonomik Şiddet } & \multicolumn{2}{|c|}{ Toplam } \\
\hline & f & $\%$ & f & $\%$ & f & $\%$ & f & $\%$ & f & $\%$ \\
\hline Müslüm & 13 & 62 & 7 & 33 & 0 & 0 & 1 & 5 & 21 & 17.5 \\
\hline Recep İvedik 5 & 13 & 41 & 17 & 54 & 1 & 5 & 0 & 0 & 31 & 25.8 \\
\hline Recep İvedik 4 & 9 & 27 & 20 & 59 & 4 & 11 & 1 & 3 & 34 & 28.3 \\
\hline Düğün Dernek 2 & 8 & 42.1 & 11 & 57.8 & 0 & 0 & 0 & 0 & 19 & 15.8 \\
\hline Dağ 2 & 14 & 93.3 & 1 & 6.6 & 0 & 0 & 0 & 0 & 15 & 12.5 \\
\hline Toplam & 57 & 47.5 & 56 & 46.6 & 5 & 4.1 & 2 & 1.6 & 120 & 100 \\
\hline
\end{tabular}

Filmlerde sergilenen fiziksel şiddet türünde ilk sırada kavga/dövüş/boğuşma eylemi gelmektedir. Bu eylemin yüzdesi \%24,5'tir. Bu kategoride 2. Sirada itmek/yaralamak ve 1slatmak/cisim firlatmak eylemi \%19,2'lik bir yüzdeyle gelmektedir. 3. Sırada öldürmeye kastetme/cinayet/silahlı çatışma eylemi bunlardan sonra da son sırada hırpalamak/tokat atmak eylemi gelmektedir. En çok fiziksel şiddet içeren filmler sıralamasında Dă 2 filmi ilk sırada yer alırken onları sırasıyla Müslüm ve Recep İvedik 5, Recep Ivedik 4, Düğün Dernek 2 filmleri izlemektedir.

Tablo 2

Filmlerdeki fiziksel şiddet içeren davranışlar

\begin{tabular}{|c|c|c|c|c|c|c|c|c|c|c|c|c|c|c|}
\hline \multirow[t]{2}{*}{ Film adı } & \multicolumn{2}{|c|}{$\begin{array}{l}\text { Dövmek/ kavga } \\
\text { etmek/boğuşma }\end{array}$} & \multicolumn{2}{|c|}{$\begin{array}{l}\text { İşkence } \\
\text { yapmak }\end{array}$} & \multicolumn{2}{|c|}{$\begin{array}{c}\text { İtmek/ } \\
\text { yaralamak }\end{array}$} & \multicolumn{2}{|c|}{$\begin{array}{c}\text { Islatmak/ } \\
\text { cisim } \\
\text { firlatmak }\end{array}$} & \multicolumn{2}{|c|}{$\begin{array}{l}\text { Hirpalamak/ } \\
\text { tokat atmak }\end{array}$} & \multicolumn{2}{|c|}{$\begin{array}{c}\text { Öldürmeye } \\
\text { kastetme/ } \\
\text { cinayet }\end{array}$} & \multicolumn{2}{|c|}{ Toplam } \\
\hline & f & $\%$ & f & $\%$ & f & $\%$ & $\mathbf{f}$ & $\%$ & f & $\%$ & f & $\%$ & f & $\%$ \\
\hline Müslüm & 4 & 30.7 & 1 & 7.6 & 4 & 30.7 & 1 & 7.6 & 1 & 7.6 & 2 & 15.3 & 13 & 22.8 \\
\hline Recep İvedik 5 & 2 & 15.3 & 0 & 0 & 5 & 38.4 & 6 & 46.1 & 0 & 0 & 0 & 0 & 13 & 22.8 \\
\hline Recep İvedik 4 & 0 & 0 & 1 & 11.1 & 0 & 0 & 3 & 33.3 & 5 & 55.5 & 0 & 0 & 9 & 15.7 \\
\hline Düğün Dernek 2 & 4 & 50 & 0 & 0 & 2 & 25 & 1 & 12.5 & 1 & 12.5 & 0 & 0 & 8 & 14 \\
\hline Dağ 2 & 4 & 28.5 & 2 & 14.2 & 0 & 0 & 0 & 0 & 1 & 7.1 & 7 & 50 & 14 & 24.5 \\
\hline Toplam & 14 & 24.5 & 4 & 7 & 11 & 19.2 & 11 & 19.2 & 8 & 14 & 9 & 15.7 & 57 & 100 \\
\hline
\end{tabular}


Filmlerde sergilenen duygusal şiddet türünde ilk sırada hakaret/küfretme eylemi gelmektedir. Bu eylemin yüzdesi \%37,5'tir. Bu kategoride 2. sırada bağırmak eylemi \%35,7’lik bir yüzdeyle gelmektedir. 3. Sırada küçük düşürme eylemi bunlardan sonra da tehdit etme eylemi ve son olarak da aşağılama/dışlama eylemi gelmektedir. En çok duygusal şiddet içeren filmler sıralamasında Recep İvedik 4 filmi ilk sırada yer alırken onları sırasıla Recep Ivedik 5, Düğ̈̈n Dernek 2, Müslüm ve Dăg 2 filmleri izlemektedir.

Tablo 3

Filmlerdeki duygusal şiddet içeren davranışlar

\begin{tabular}{|c|c|c|c|c|c|c|c|c|c|c|c|c|c|c|}
\hline \multirow[t]{2}{*}{ Film adı } & \multicolumn{2}{|c|}{$\begin{array}{c}\text { Aşağılamak/ } \\
\text { dışlamak }\end{array}$} & \multicolumn{2}{|c|}{ Bağırmak } & \multicolumn{2}{|c|}{ Tehdit etmek } & \multicolumn{2}{|c|}{$\begin{array}{c}\text { Hakaret- } \\
\text { küfretmek }\end{array}$} & \multicolumn{2}{|c|}{$\begin{array}{c}\text { Küçük } \\
\text { düşürmek }\end{array}$} & \multicolumn{2}{|c|}{ Korkutmak } & \multicolumn{2}{|c|}{ Toplam } \\
\hline & f & $\%$ & f & $\%$ & f & $\%$ & f & $\%$ & f & $\%$ & f & $\%$ & f & $\%$ \\
\hline Müslüm & 0 & 0 & 4 & 57.1 & 1 & 14.2 & 2 & 28.4 & 0 & 0 & 0 & 0 & 7 & 12.5 \\
\hline Recep İvedik 5 & 2 & 11.7 & 4 & 23.5 & 2 & 11.7 & 8 & 47 & 1 & 5.8 & 0 & 0 & 17 & 30.3 \\
\hline Recep İvedik 4 & 0 & 0 & 4 & 20 & 2 & 10 & 8 & 40 & 6 & 30 & 0 & 0 & 20 & 35.7 \\
\hline Düğün Dernek 2 & 0 & 0 & 7 & 63 & 1 & 9 & 3 & 27 & 0 & 0 & 0 & 0 & 11 & 19.6 \\
\hline Dağ 2 & 0 & 0 & 1 & 100 & 0 & 0 & 0 & 0 & 0 & 0 & 0 & 0 & 1 & 1.7 \\
\hline Toplam & 2 & 3.5 & 20 & 35.7 & 6 & 10.7 & 21 & 37.5 & 7 & 12.5 & 0 & 0 & 56 & 100 \\
\hline
\end{tabular}

Filmlerde şiddete maruz kalanların cinsiyete göre dağılımı kategorisinde erkekler \%75'lik oranla kadınların önündedir. Erkeklerin en çok şiddete maruz kaldığı film \%95'lik oran ile Dügün Dernek 2'dir. Kadınların en fazla şiddet eylemine maruz kaldığ

Tablo 4

Filmlerde şiddete maruz kalanların cinsiyete göre dağglımı

\begin{tabular}{|c|c|c|c|c|c|c|}
\hline \multirow{2}{*}{ Film Adı } & \multicolumn{2}{|c|}{ Erkek } & \multicolumn{2}{|c|}{ Kadın } & \multicolumn{2}{|c|}{ Toplam } \\
\hline & $\mathbf{f}$ & $\%$ & f & $\%$ & $\mathbf{f}$ & $\%$ \\
\hline Müslüm & 13 & 62 & 8 & 38 & 21 & 17.5 \\
\hline Recep İvedik 5 & 26 & 83.3 & 5 & 16.1 & 31 & 25.8 \\
\hline Recep İvedik 4 & 21 & 61.7 & 13 & 38.2 & 34 & 28.3 \\
\hline Düğün Dernek 2 & 18 & 95 & 1 & 5 & 19 & 15.8 \\
\hline Dağ 2 & 12 & 80 & 3 & 20 & 15 & 12.5 \\
\hline Toplam & 90 & 75 & 30 & 25 & 120 & 100 \\
\hline
\end{tabular}

Filmlerde faili erkek olan şiddet eylemi en çok \%27,8'lik oranlarla Recep Ívedik 4 ve Recep İvedik 5 filmlerinde tespit edilmiştir. Bu filmleri sırasıyla Müslüm, Dă̆ 2 ve Dügü̈n Dernek 2 filmleri takip etmektedir. Araştırmaya göre filmlerde erkekler en çok fiziksel şiddetin faili durumundadır. Erkeklerin uyguladığı fiziksel şiddetin oranı $\% 50$ olurken duygusal şiddettin oranı ise $\% 42,3$ olmuştur.

Tablo 5

Filmlerde faili erkek olan şiddet eylemleri ve şiddetin türü

\begin{tabular}{|c|c|c|c|c|c|c|c|c|c|c|}
\hline \multirow{2}{*}{ Film adı } & \multicolumn{2}{|c|}{ Fiziksel şiddet } & \multicolumn{2}{|c|}{ Duygusal şiddet } & \multicolumn{2}{|c|}{ Cinsel şiddet } & \multicolumn{2}{|c|}{ Ekonomik şiddet } & \multicolumn{2}{|c|}{ Toplam } \\
\hline & f & $\%$ & f & $\%$ & f & $\%$ & f & $\%$ & f & $\%$ \\
\hline Müslüm & 12 & 63.1 & 6 & 31.5 & 0 & 0 & 1 & 5.2 & 19 & 18.2 \\
\hline Recep İvedik 5 & 14 & 48.2 & 14 & 48.2 & 1 & 3.4 & 0 & 0 & 29 & 27.8 \\
\hline Recep İvedik 4 & 8 & 27.5 & 15 & 51.7 & 4 & 13.7 & 2 & 6.8 & 29 & 27.8 \\
\hline Düğün Dernek 2 & 4 & 33.3 & 8 & 66.7 & 0 & 0 & 0 & 0 & 12 & 11.5 \\
\hline Dağ 2 & 14 & 93.3 & 1 & 6.6 & 0 & 0 & 0 & 0 & 15 & 14.4 \\
\hline Toplam & 52 & 50 & 44 & 42.3 & 5 & 4.8 & 3 & 2.8 & 104 & 100 \\
\hline
\end{tabular}

Filmlerde faili kadın olan şiddet eylemi en çok \%50'lik oranlarla Düğün Dernek 2 fillminde tespit edilmiștir. Bu filmi sırasıyla Recep İvedik 4, Müslüm ve Recep İvedik 5 filmleri takip etmektedir. Dă 2 filminde kadınların faili olduğu şiddet eylemine rastlanmamıştır. Araştırmaya göre filmlerde kadınlar en çok duygusal şiddetin faili durumundadır. Kadınların uyguladığı duygusal şiddetin oranı \%57,1 olurken fiziksel şiddettin oranı ise $\% 42,8$ olmuştur.

Tablo 6

Filmlerde faili kadın olan şiddet eylemleri ve şiddetin türü

\begin{tabular}{|c|c|c|c|c|c|c|c|c|c|c|}
\hline \multirow{2}{*}{ Film adı } & \multicolumn{2}{|c|}{ Fiziksel şiddet } & \multicolumn{2}{|c|}{ Duygusal șiddet } & \multicolumn{2}{|c|}{ Cinsel şiddet } & \multicolumn{2}{|c|}{ Ekonomik șiddet } & \multicolumn{2}{|c|}{ Toplam } \\
\hline & f & $\%$ & f & $\%$ & f & $\%$ & f & $\%$ & f & $\%$ \\
\hline Müslüm & 1 & 50 & 1 & 50 & 0 & 0 & 0 & 0 & 2 & 14.2 \\
\hline Recep İvedik 5 & 0 & 0 & 2 & 100 & 0 & 0 & 0 & 0 & 2 & 14.2 \\
\hline Recep İvedik 4 & 1 & 33.3 & 2 & 66.7 & 0 & 0 & 0 & 0 & 3 & 21.4 \\
\hline Düğün Dernek 2 & 4 & 57.1 & 3 & 42.8 & 0 & 0 & 0 & 0 & 7 & 50 \\
\hline Dağ 2 & 0 & 0 & 0 & 0 & 0 & 0 & 0 & 0 & 0 & 0 \\
\hline Toplam & 6 & 42.8 & 8 & 57.1 & 0 & 0 & 0 & 0 & 14 & 100 \\
\hline
\end{tabular}

Filmlerde faili kadın olan şiddet eylemi en çok \%50'lik oranlarla Düğün Dernek 2 filminde tespit edilmiştir. Bu filmi sırasıyla Recep İvedik 4, Müslüm ve Recep İvedik 5 filmleri takip etmektedir. Dă̆ 2 filminde kadınların faili 
olduğu şiddet eylemine rastlanmamıştır. Araştırmaya göre filmlerde kadınlar en çok duygusal şiddetin faili durumundadır. Kadınların uyguladığı duygusal şiddetin oranı \%57.1 olurken fiziksel şiddettin oranı ise \%42.8 olmuştur.

\subsection{Filmlere özgü değerlendirmeler}

Araştırmanın bu bölümünde incelenen filmlerdeki şiddet olgusunun sadece sayısal verilerle değerlendirmenin yetersiz olacağı düşünülerek araştırmacının filmler hakkındaki gözlemlerine yer verilmiștir.

\subsubsection{Müslüm}

Biyografik bir film olan Müslüm de şiddet eylemi toplamda 21'dir. Bu filmde zaman zaman şiddetin sunumunda metaforik öğeler kullanılmıştır. Örneğin, Müslüm'ün babasının annesini öldürdüğü sahne ile güvercin kafesine giren kedi eş zamanlı bir kurgu ile izleyiciye sunulmuştur. Böylece baba ve kedi; güvercinler ve anne arasında metaforik bir bă̆ kurulmuştur. Müslüm Gürses'in eşi Muhterem Nur'a evlendikten sonra uyguladığı şiddet direk olarak gösterilmese de ima edilir. Bu durum erkek şiddeti kavramını akla getirir. Erkeğin şiddeti bir egemenlik aracı olarak kullandığını öne süren görüşler mevcuttur. Şentürk'e (2017) göre, "farklı erkeklik biçimleri farklı erkek şiddetleri, ya da erkeklerin şiddet ile kurduğu farklı ilişki biçimlerini de beraberinde getirmektedir"( s. 37), Filmde hayranlarının baba olarak gördüğü Müslüm Gürses, yaygın bir erkeklik davranışı olarak ve aynı zamanda hegemonik erkekliğin babaya atfettiği bir davranış biçimi olarak eşine yani Muhterem Nur'a şiddet uygulamaktadır. Bu açıdan bakıldığında Müslüm filminde hegemonik erkekliğin bir sunumunu görmek mümkündür.

\subsubsection{Recep İvedik 5}

Recep İvedik 5 filminde toplamda 31 tane şiddet eylemi tespit edilmiştir. Duygusal şiddetin oranı daha yüksektir. Filmdeki hakaret/küfür eylemi en sık rastlanan şiddet eylemidir. Recep İvedik karakteri sık sık hakaret ve küfür içeren şiddet eylemlerini tekrarlar. Bu filmde şiddet eylemleri olay örgüsünün gereği olarak değil öncelikli olarak mizah unsuru olarak işlev görmektedir.

Bu filmde baş karakter Recep İvedik'in şiddet eylemlerine baktığımızda ayrımcılık, küfür ve hakaret, kişiye fiziksel şiddet uygulamak gibi pek çok eyleme tanık oluruz. Filmin başından itibaren Recep İvedik karakteri sınırsız bir özgürlükle filmin diğer kişilerine karşı duygusal ve fiziksel şiddet eyleminde bulunurken sergilediği "maganda" tavırları ile izleyiciye de kötü bir örnek olmaktadır. Bu bağlamda Recep İvedik karakteri şiddeti normalleștiren bir toplumsal etki yaratır. Diğer bir değişle Recep İvedik serisinin diğer filmleri gibi bu filmde de şiddet meşrulaştırılmaktadır. Toplumsal psikoloji anlamında şiddet eylemlerinin normalleştirilmesi şiddete maruz kalan bireyleri şiddete karşı sessiz kalma davranışına itmektedir.

\subsubsection{Dă̆ 2}

Dă̆ 2 filmi çok sayıda fiziksel şiddet eylemi içeren bir filmdir. Bu filmdeki şiddet içeriğinin çoğunluğunda karşılıklı çatışma, öldürme, yaralama ve boğuşma eylemleri bulunmaktadır. Filmin savaş içeren sahnelerindeki bireysel ve kolektif çatışmalar şiddet içeriğini yoğunlaştırmıştır. Çatışma unsurlarını gerçekçi kılabilmek için özel efektler kullanılmıştır. Ayrıca bazı şiddet sahnelerinde seyirci üzerinde etkiyi arttırmak için yavaş çekimler kullanılmıştır.

Bu filmdeki savaş sahnelerinin yoğunluğu, militarizm ve şiddet ilişkisini akla getirmektedir. Askerliği ve savaş1 yücelten bir anlayış olan militarizm, şiddeti de onaylayan bir yapıdadır. Militarist düşünce yapısı, savaşı kaçınılmaz olarak görür ve şiddeti militarist bireyin vazgeçilmez bir aracı olarak değerlendirir. Militarist bağlamda Dağ 2 filmi şiddeti ve çatışmayı olumlamaktadır. Şiddet uygulamak cesaret, kahramanlık, vatanseverlik, onur gibi kavramların bir gereği gibi sunulmaktadır. Filmin başlarında savaş karşıtı bir gazeteci olan Ceyda Balaban karakterinin, filmin sonlarına doğru savaşı ve şiddeti haklı gören bir yapıya bürünmesi de bu filmin savaşı ve şiddeti yücelten militarist anlayışını yansıtmaktadır.

\subsubsection{Düğün Dernek 2}

Düğ̈̈n Dernek 2 filmi örneklemdeki diğer komedi filmleri olan Recep İvedik 4 ve Recep İvedik 5 filmleri kadar olmasa da şiddet eylemi içermektedir. Bu filmde sergilenen toplam 19 şiddet eyleminin 7 tanesinin faili kadındır. Diğer filmlere nazaran bu filmde kadınların uyguladığı şiddetin de önemli bir rolü vardır. Duygusal şiddet içeren sahneler bu filmde yoğunluktadır. Duygusal şiddet içeren sahneler karşılıklı diyaloglarda verilirken fiziksel şiddet eylemlerinin olay örgüsünde önemli işlevi olmuştur.

Düğün Dernek 2 fillmi yoğun bir duysal şiddet içermesine rağmen küfür ve hakaret gibi duygusal şiddet unsurlarını çok az barındırmaktadır. Bu film sözel şiddeti komedi malzemesi olarak kullanmak yerine oyunculukları öne çıkararak izleyiciyi güldürmeyi hedeflemiştir. "Yönetmen Selçuk Aydemir, Düğ̈̈n Dernek 2 filminde Oyuncuların konuşma biçimleri ve mimikleri ile jestleri izleyici üzerinde gülme hissi yaratmaktadır" (Çöteli, 2016, s. 275). Bu bağlamda bu filmdeki şiddetin örneklemdeki diğer filmler kadar baskın bir unsur olmadığını söyleyebiliriz. 


\subsubsection{Recep İvedik 4}

Recep İvedik 4 filmi bir komedi filmi olmasına rağmen örnekleme dahil edilen filmler içerisinde en yüksek şiddet eyleminin olduğu filmdir. Sözel duygusal şiddet bu filmde sıklıkla görülmektedir. Duygusal şiddet eylemlerinin yaklaşı 25 tanesinin faili Recep İvedik karakteridir. Recep İvedik filmdeki diğer karakterlere uyguladığ duygusal şiddet ile otorite ve düzen karşııı kimliğini yansıtmaktadır. Bu filmde şiddet içeriğinin kullanımı mizah duygusunu güçlendirmek içindir. Filmdeki şiddet içeriğinin olay örgüsünde bir işlevi bulunmamaktadır.

\section{Sonuc}

Şiddetin sinemada kullanımının pek çok amacı olabilir. Olay örgüsünün gelişimini sağlamak için, karakter sunumunda, mizah öğesi olarak ya da ana fikrin vurgulanmasında şiddet unsuru filmlerde kullanılabilir. Bunların dışında izleyiciyi etkilemekte de şiddet kullanılabilir. Filmlerde gerçeklik duygusunu yaratmakta da şiddet unsuru kullanılabilir.

Müslüm ve Dağ 2 filmlerinde yer alan fiziksel şiddet içeriği gerçeğe yakın şekilde sunulmuş böylece izleyicinin gerçeklik duygusunu hissetmesi sağlanmıştır. Şiddetin yarattığı bu gerçeklik aynı zamanda filmlerinde ürettiği bir gerçekliktir. Üretilen şiddetin gerçekçiliği izleyicinin gerçeklik algısını doğrudan etkilemektedir. Buna göre izleyicinin film izlerken hissettiği duyguların üretilmesinde şiddet önemli bir unsurdur.

İzleyiciyi güldürmek için de şiddet sinemada kullanılabilir. Komedi filmleri olarak değerlendirilebilecek Recep İvedik 5, Recep İvedik 4 ve Dügü̈n Dernek 2 filmlerinde şiddet içeren pek çok sahne mevcuttur.

İzleyiciyi etkilemek sinema sanatı için önemli bir amaçtır. Farklı yollarla da olsa filmlerde izleyiciyi etkilemek için şiddet kullanılabilir. Ancak şiddettin sinemada kullanımı her zaman tartışma konusu olmuştur. Diğer medya araçlarında olduğu gibi sinemada yer alan şiddetin de birey üzerindeki etkisi araştırma konusu olmuştur. Yapılan bu araştırmalarda sinemada şiddet genellikle olumsuzlanan bir durum olarak değerlendirilmiştir.

$\mathrm{Bu}$ çalışma dahilinde ele alınan filmlerde şiddetin kulanım amacı; olay örgüsünü ilerletme, karakter sunumu, mizah ve gerçeklik duygusunu pekiştirmedir. Bu amaçlarla temelde şiddet, sinemanın izleyiciye sunduğu görsel ve işitsel bir şov olarak görülebilir.

Filmlere özgü durumlara baktığımızda Müslüm filminde hegemonik erkeklik olgusunun öne çıktığını görüyoruz. Dağ 2 filminde ise şiddeti kutsayan militarist bir bakış açısı var. Recep İvedik filmlerinde ise mizah yoluyla şiddet normalleştirilmiştir. Düğün Dernek 2 filmi ise kadın karakterler şiddetin öznesi olurken diğer taraftan şiddet bu filmde diğer filmler kadar baskın değildir.

Filmler yoluyla görsel ve işitsel bir şov haline gelen şiddetin sunum biçimi de önemli bir nokta haline gelmiştir. Bireye yönelik fiziksel şiddetin detaylı sunumu veya galiz küfürler, ağır hakaretler içeren sahneler izleyicide rahatsızlık yaratıp filmin gişesini olumsuz etkileyebilir. Bu durum genellikle ekonomik durumu iyi olan izleyiciye göre veya toplumun sahip olduğu değer yargılarının zamanla değişmesiyle beraber değişkenlik gösterebilir. Örneğin bugün herkesin güldüğ̈̈ şiddet içeren bir sahne ileride ayıplanacak bir durum olarak değerlendirilebilir. $\mathrm{Bu}$ bağlamda yüksek izleyici sayısına ulaşan filmlerdeki şiddet içeriğinin toplumu rahatsız etmeyecek düzeyde tutulduğu söylenebilir.

Genel itibariyle araştırmadan çıkan sonuçlara bakıldığında

- Filmlerde sergilenen şiddetin türü kategorisinde ilk sırada fiziksel şiddet vardır. Fiziksel şiddet kadar yoğun olan bir başka şiddet türü de duygusal şiddettir.

- Filmlerde sergilenen fiziksel şiddet türünde ilk sırada kavga/dövüş/boğuşma eylemi gelmektedir. Bu kategoride 2. Sirada itmek/yaralamak ve islatmak/cisim firlatmak eylemi gelmektedir.

- Filmlerde sergilenen duygusal şiddet türünde ilk sırada hakaret/küfretme eylemi gelmektedir. Bu kategoride 2. sırada bağırmak eylemi gelmektedir.

- Filmlerde şiddete maruz kalanların cinsiyete göre dağılımı kategorisinde erkekler kadınların önündedir. Erkeklerin en çok şiddete maruz kaldığ film Düğün Dernek 2'dir. Kadınların en fazla şiddet eylemine maruz kaldığ film ise Recep Ívedik 4'tür.

- Filmlerde faili erkek olan şiddet eylemi en çok Recep İvedik 4 ve Recep İvedik 5 filmlerinde tespit edilmiştir. Bu filmleri sırasıyla Müslüm, Dă̆ 2 ve Düğün Dernek 2 filmleri takip etmektedir. Araştırmaya göre filmlerde erkekler en çok fiziksel şiddetin faili durumundadır.

- Filmlerde faili kadın olan şiddet eylemi en çok Dügün Dernek 2 filminde tespit edilmiştir. Bu filmi sırasıyla Recep İvedik 4, Müslüm ve Recep İvedik 5 filmleri takip etmektedir. Dă̆ 2 filminde kadınların faili olduğu şiddet eylemine rastlanmamıştır.

$\mathrm{Bu}$ araştırmada elde edilen sonuçları daha önce yapılan araştırmaların sonuçlarıyla karşılaştırılması gerekmektedir. Gökulu'nun 2013 yılında yaptığı araştırmanın sonuçlarına göre Türk yapımı sinema filmlerinde ve dizilerde cinsel şiddet yoğundur. Ancak bu araştırmanın sonuçlarına göre cinsel şiddetin yoğunluğu diğer şiddet türlerine nazaran 
daha azdır. Abisel'in 2005 yılında Yeşilçam filmleri üzerine yaptığı araştırmada kadınlara yönelik şiddetin yoğun olduğu sonucuna ulaşmıştır. Bu araştırmada da kadınlara yönelik şiddet eylemleri özellikle Recep Ivedik serisi filmlerde ve Müslüm filminde yoğundur.

Bu sonuçların dışında yüksek izleyici sayısına ulaşan filmlerde şiddetin kullanımı değerlendirildiğinde; bazı şiddet türlerinin öne çıktığı, bu şiddet biçimlerinin genellikle ikili diyaloglarda ya da birbirine yabancı film kişileri arasında gerçekleştiği görülmüştür. Ayrıca incelenen filmlerde şiddetin sunumunda görsel ve işitsel unsurlar izleyiciyi etkileme amacıyla yoğun bir şekilde kullanılmıştır. Bireye doğrudan zarar verme amacı taşıyan şiddet eylemlerini içeren filmlerin yüksek izleyici kitlesine ulaşması, bu durumun toplumsal bir sorun olarak görülüp değerlendirilmesi gerekliliğini ortaya çıkarmaktadır.

\section{Kaynakça}

Abisel, N. (2005). Türk Sineması üzerine yazılar. Ankara: Phoenix Yayınevi.

Atabek, G., \& Atabek, Ü. (2007). Medya metinlerini çözümlemek içerik göstergebilim ve söylem çözümleme yöntemleri. Ankara: Siyasal Kitabevi.

Ayrancı, Ü., Köşgeroğlu, N., \& Günay, Y. (2004). Televizyonda çocukların en çok seyrettikleri saatlerde gösterilen filmlerdeki şiddet düzeyi. Anadolu Psikiyatri Dergisi, 5(3),133-140.

Bagdikian, B.H. (2000). The media monopoly. Boston: Beacon Press.

Balcığlu, İ. (2001). Şiddet ve toplum. İstanbul: Bilge Yayıncılık.

Berelson, B. (1952). Content analysis in communication research. New York: The Free Press.

Bilgin, N. (2006). Sosyal bilimlerde içerik analizi teknikler ve örnek çallşmalar. Ankara: Siyasal Kitabevi.

Birleşmiş Milletler. (2009). Violence against worlds women. (Araştırma Raporu). Erişim adresi: https://unstats.un.org/unsd/demographicsocial/products/worldswomen/documents/Violence\%20against\%20w omen.pdf

Browne, N., Webb, T., Fisher, K., \& Cook, B. (2002). American film violence an analytic portrait. Journal Of Interpersonal Violence, 17(4), 351-370. doi: https://doi.org/10.1177/0886260502017004001

Burks, H. L., \& Harrison, S. I. (1962). Aggressive behavior as a means of avoiding depression. American Journal of Orthopsychiatry. 32, 416-422. doi: https://doi.org/10.1111/j.1939-0025.1962.tb00291.x

Çöteli, S. (2016). Yeni dönem orta oyunu: Türk Sinemasında komedi ve Selçuk Aydemir. G. Parlayandemir \& Y. D. Birincioğlu (Ed.), Tür(k) sinemasında auteurler 2000 sonrası Türk Sinemasında türler ve yönetmenler (s.263-291) içinde. İstanbul: Kriter Yayınevi.

Di Martino, V. (2003). Workplace violence in the health sector: relationship between work stress and workplace violence in the health sector. (Araştırma Raporu). Erişim adresi: https://www.who.int/

Dünya Sağlık Örgütü. (2002). World report on violence and health. (Araştırma Raporu). Erişim adresi: http://www.who.int/violence_injury_prevention/violence/global_campaign/en/chap6.pdf

Erdal Aytekin, P. (2015). Zeki Demirkubuz sinemasında şiddet: Masumiyet ve kader. Ankara Üniversitesi ILEEF Dergisi, 2(2), 155-178. doi: https://doi.org/10.24955/ilef.305321

Erten, Y., \& Ardalı, C. (1996). Saldırganlık şiddet ve terörün psikososyal yapıları. Cogito, sayı 6-7, Kış-Bahar,143164.

Gerbner, G. (1996). The Hidden side of television violence. H. Schiller (Ed.), Invisible Crisis (s. 27-34) içinde. Colorado: Westview Press.

Gerbner, G. (1998a). The Stories we tell. Kültür ve Illetişim, 1(1), 17-30. doi: https://doi.org/10.1080/ 10402659908426225

Gerbner, G. (1998b). Stories of violence and the public interest. J. H. Brants \& L. Van Zoonen (Ed.), The media in question, (s.135-46). London: Sage Publication.

Gerbner, G., Signorielli, N., Gross, L., \& Morgan, M. (1980). Aging with television: images on television drama and conceptions of social reality. Journal of Communication, 30(1), s. 37-47. doi: https://doi.org/10.1111/ j.1460-2466.1980.tb01766.x

Gökulu, G. (2013). Representation of sexual violence in Turkish Cinema and television series. Asian Journal of Women's Studies, 19(2), 66-91. doi: https://doi.org/10.1080/12259276.2013.11666149 
Gümüş A. (2006). Şiddet türleri. Toplumsal Bir Sorun Olarak Şiddet Sempozyumunda sunulan bildiri, EğitimSen, Ankara. Erişim adresi: http://egitimsen.org.tr/wp-content/uploads/2016/11/\%C5\%9Eiddet-T\%C3\% BCrleri.pdf

Gürkan, Ö. C., \& Coşar, F. (2009). Ekonomik şiddetin kadın yaşamındaki etkileri. Uluslararası Disiplinler Arası Kadın Çalışmaları Kongresinde sunulan bildiri, Sakarya Üniversitesi, Sakarya. Erişim adresi: http://hemsirelik.maltepe.edu.tr/dergiler/cilt2sayi3/cilt2sayi3/124-129.pdf

Head, S. W. (1954). Content analysis of television drama programs. The Quarterly of Film Radio and Television, 9(2), 175-194. doi: https://doi.org/10.2307/1209974

Holsti, O. R. (1969). Content analysis for the social sciences and humanities. Reading: Addison-Wesley Publication.

Kalkan, H. S. (2018). Şiddet mi? Hani nerede? Psikesinema Dergisi, 15, 70-76.

Köknel, Ö. (2000). Bireysel ve toplumsal şiddet. İstanbul: Akdeniz Yayıncılık.

Krippendorf, K. (1980). Content analysis: an introduction to its methodology. New York: Sage Publication.

Michaud, Y. (1991). Şiddet (C. Muhtaroğlu, Çev.). İstanbul: İletişim Yayınları.

Moses, R. (1996). Şiddet nerede başlıyor? (A. Kul, Çev.). Cogito, sayı: 6-7, Kış- Bahar, 24- 27.

Özbay, G., \& Kutlu, N. (1993, 14 Aralık). TV'lerde ölüm makinası filmler. Milliyet, s. 7-8.

Özer, Ö. (2010). Giriş: medyada şiddet kültürü. Ö. Özer (Ed.), Medyada şiddet kültürü- Bu öyküde sen anlatılıyorsun (s. 11-36) içinde. İstanbul: Literatürk Yayınları.

Özer, Ö. (2017). Medyada şiddet kullanımı: şiddet ekonomisi, medyanın ideolojik şiddeti ve yetiştirme kuramı açısından bir değerlendirme. Marmara İletişim Dergisi, 27. 1-19. doi: https://doi.org/10.17829/midr. 20172729519

Özer, Ö., \& Saraçer Üçer, N. (2010). "Baba 1" ve "Kurtlar Vadisi Irak” filmleri örneğinde sinemada şiddetin kullanımı. Ö. Özer (Ed.), Medyada şiddet kültürü- Bu öyküde sen anlatıllyorsun (s. 269-292) içinde. İstanbul: Literatürk Yayınları.

Pişkin, G. (2007). Huzlı ve dengesiz değişime tepki olarak sinemada şiddet Türkiye örneği 1980-2006. Icanas 38. Uluslararası Asya ve Kuzey Afrika Çalışmaları Kongresinde sunulan bildiri, Atatürk Kültür-Dil ve Tarih Yüksek Kurumu, Ankara. Erişim adresi: https://www.ayk.gov.tr/

Polat, O. (2017). Şiddet. Marmara Üniversitesi Hukuk Fakültesi Hukuk Araştırmaları Dergisi, $22(1), 15$ - 34. Erişim adresi: https://dergipark.org.tr/tr/download/article-file/274326

Potter, W. J. (1999). On media violence. London: Sage Publication.

Slocum, J. D. (2000). Film violence and the institutionalization of the cinema. Social Research, 67(3), 649-681. Erişim adresi: https://www.jstor.org/stable/40971406?seq=1

Stone, B. (2016). Religion and violence in popular film. Journal of Religion \& Film, 1(3), Article 5. Erişim adresi: https://digitalcommons.unomaha.edu/jrf/

Süalp, Z. T. A. (1993). Şehir, şiddet ve sinema. Psikiyatri, Psikoloji, Psikofarmokoloji Dergisi, 1(4), 1-15. Erişim adresi: https://www.academia.edu/5325846/\%C5\%9Eehir \%C5\%9Eiddet ve Sinema

Şentürk, B. (2017). Şiddet ve erkeklikler: av mevsimi ve gönül yarası filmleri üzerinden Türkiye'deki erkeklik biçimlerine bakmak. Anemon Muş Alparslan Üniversitesi Sosyal Bilimler Dergisi, 5(1), 27-44. doi: https://doi.org/ 10.18506/anemon.xxxxxxxx

Tekin, Ü. (2011). Şiddet! şiddet kavramı, aile içi şiddet, kadına yönelik şiddet ve çocuk istismarı. Ankara: Orient Yayınlar1.

Teksoy, R. (2007). Rekin Teksoy’un Türk sineması kitabı. İstanbul: Oğlak Yayıncılık.

Temel, S. (2008). Sinema filmlerinde şiddet içeriğinin yeniden üretimi (Yüksek Lisans Tezi). YÖK tez veri tabanından erişildi (Tez No. 218863).

Trend, D. (2008). Medyada şiddet efsanesi eleştirel bir giriş. (G. Bostanc1, Çev.). İstanbul: Yapı Kredi Yayınları.

Turam, E. (1996). Tv'deki şiddetin çocuklara etkileri üzerine farklı bir bakış. Cogito, sayı 6-7, Kış-Bahar, 391406. 
Türk Sineması ve Şiddet: Son Dönem Türk Filmlerinde Şiddetin Sunumu Üzerine Bir Araştırma

GSED, 2020; Cilt: 26, Say1: 44: 246-257 - DOI: 10.32547/ataunigsed.674233

Türk Dil Kurumu Türkçe Sözlük. (t.y.). Şiddet. Erişim adresi: https://sozluk.gov.tr/

Ünsal, A. (1996). Genişletilmiş bir şiddet tipolojisi. Cogito, sayı 6-7, Kış-Bahar, 29-36. 